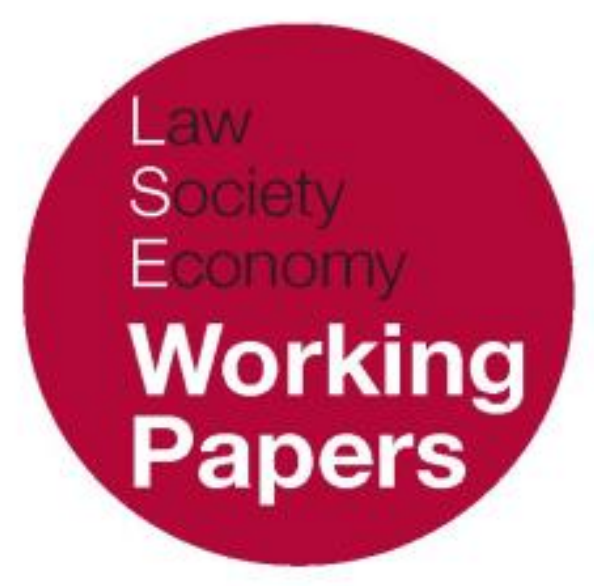

\title{
Non-Citizens as Subjects of the Criminal Law
}

\author{
Emmanuel Melissaris
}

LSE Law, Society and Economy Working Papers 2/2017

London School of Economics and Political Science

Law Department

This paper can be downloaded without charge from LSE Law, Society and Economy Working Papers at: www.lse.ac.uk/collections/law/wps/wps.htm and the Social Sciences Research Network electronic library at: https://papers.ssrn.com/sol3/papers.cfm?abstract_id=2921023. (C) Emmanuel Melissaris. Users may download and/or print one copy to facilitate their private study or for non-commercial research. Users may not engage in further distribution of this material or use it for any profit-making activities or any other form of commercial gain. 


\title{
Non-Citizens as Subjects of the Criminal Law
}

\author{
Emmanuel Melissaris *
}

\begin{abstract}
The article has a dual aim. The first is to contribute to the study of criminalisation at the border in Europe by outlining some ways in which Greek law organises the normative exclusion of at least one class of immigrants. Secondly, it tackles the theoretical question of whether such practices are justifiable. No sooner is a non-citizen involved in the criminal law that a web of duties and rights is activated marking the gradual inclusion of the non-citizen in the political community as its proper subject. This renders the differential treatment of noncitizens incoherent. The article also argues that it is both permissible and necessary for a state to treat non-citizens as the proper subject of the criminal law. The former because of the implicit consent provided by non-citizens; the latter out of the respect owed to citizens, whose normative position is impacted upon by their criminal law related interactions with noncitizens.
\end{abstract}

\footnotetext{
* Department of Law, London School of Economics and Political Science. I am indebted to Maria Voutsinou, Nicola Lacey, Zelia Gallo, Antony Duff, Federico Picinali, Ntina Tzouvala, Andreas Takis, and Neil Duxbury for their advice and comments on drafts of this article. I am also grateful to Natassa Mavronicola, Antje du Bois-Pedain, Vincent Chiao, and Youngiae Lee for discussions on the themes of the article. I also benefitted from presenting the central ideas to the audience of the "Current Issues in Criminal Law" conference at the Aristotle University of Thessaloniki in December 2016. I am solely responsible for all remaining errors of fact or judgement.
} 
This article has a dual aim. First, it will attempt to make a contribution, however modest, to the growing and very important literature on the criminology of mobility. In particular, it will outline some aspects of the criminal law-related treatment of third country nationals without leave to remain (hereinafter third country nationals ${ }^{1}$ for brevity) in Greece, which is along with Italy the main country of first arrival in Europe. ${ }^{2}$ It will then highlight some consequences of and patterns emerging from the ways in which third country nationals become subjects of the criminal law. It will not do so from the criminological perspective of focusing on actual practices but rather by offering a theoretical discussion of the way in which criminal law instruments are constructed and structured so as to organise the normative marginalisation of third country nationals from the political communities of Greece - although, almost certainly, the same argument can be made in other contexts too. This normative marginalisation by the criminal law contributes to and, to an extent, facilitates the physical exclusion of third country nationals by legitimising it. It also undermines their integration in networks of social relations with those with a right to be in the country.

The second aim is to develop a critique of practices of treating aliens through the criminal law by drawing arguments from the logic of the criminal law itself as an integral part of the legal system as a whole. The crux of the claim is that no sooner does a host country implicate a third country national in its criminal law than certain duties on its part are generated to treat the third country national in a certain way, duties which crimmigration practices violate. I will also make some brief remarks on why it might be permissible for a host state to implicate third country nationals in the criminal law as well as on whether there are any compelling reasons for a host state to treat third country nationals as proper subjects of the criminal law and the legal system at large.

\footnotetext{
${ }^{1}$ I use the term 'third country national' rather than 'aliens' in order to draw the distinction between EU and non-EU nationals. Nevertheless, the term is still wider than the category of people, to which the chapter refers. Some, for example those who seek asylum or those deserving of international protection, form sub-categories of third country nationals and are excluded from the ambit of the provisions discussed here. However, even many of those who would fall under these exceptions in practice do not for a number of reasons: they might not have the relevant information to request recognition of their status, they might not want their status to be recognised and so on. A reasonable question to ask is how many people might be covered by the criminal laws, to which I refer in this article. The number of irregular migrants is notoriously difficult to estimate. The only thing that one can say with any certainty is that there are some 20,000 people without leave to remain, who have already lived in Greece for seven years and have applied for leave (and have therefore been granted immunity from being returned to their points of origin). A rough, unofficial estimate of the total number is at least 150,000.

${ }^{2}$ The International Organization for Migration provides up to date information on migration flows into Europe: http://migration.iom.int/europe/.
} 


\section{2 'CRIMMIGRATION' IN GREECE: IMPLICATING THIRD COUNTRY NATIONALS IN THE CRIMINAL LAW}

Let me start with a brief outline, without going into much technical detail, of some ways in which third country nationals in Greece are implicated in the criminal law and the ramifications of this implication for their status. The list that follows is by no means exclusive. It does, however, include some central criminal law institutions governing crucial junctures of third country nationals' existence in Greek territory.

Third country nationals tend to be treated as subjects of the criminal law as soon as they reach the country's border. The Greek Immigration and Social Integration Code (Law 4251/2014, hereafter ISIC), which consolidated and amended previous legislation and introduced a number of new provisions, provides - in-line with the Schengen Agreement and its Implementation Convention - that a third country national can be refused entry into the country. ${ }^{3}$ Among other reasons, such as not possessing the appropriate documents, entry can be refused if the third country national is registered in the Schengen Information System as an unwanted alien or if she poses a threat to public order, national security, public health, or the international relations of an EU Member State. There is a presumption that such a threat is posed if the third country national is registered in the list of unwanted aliens (more on which below). Those included in the list must leave the country immediately. Otherwise, they are redirected either to the country of provenance or to a third country. The welcome amendment that the ISIC introduced in relation to previous legislation is that the executive is under an obligation fully and expressly to ground entry refusal decisions.

The same requirements follow third country nationals after they have already entered Greek territory. The ISIC maintains two central procedures from the relevant provisions of Law 3386/2005 for expelling third country nationals on the basis of their implication in the criminal law (alongside other grounds). ${ }^{4}$

According to Art. 82, a list of unwanted aliens is kept with the criteria of inclusion in the list being determined by the executive. These are currently: a previous administrative or judicial extradition order; the third country national's presence in the country posing a threat to national security or public order with the presumption that such a threat is posed when there are serious grounds for believing that he has committed serious criminal offences or there is clear

\footnotetext{
3 This does not apply to those seeking asylum or deserve international protection. In those cases, the procedure is governed by the Geneva Convention and Law 4375/2016, which implements Directive 2013/33/EU. Nevertheless, it is possible, and there have been such cases, that people who want to enter the country and join close relatives who have already been granted, often indefinite, leave to remain are refused entry on grounds of national security and public order on the basis of this article of the ISIC. Authorities tend to apply this extensively even in cases in which it is quite obvious that no threat to national security is posed (for example, elderly relatives have been known to have been refused entry because they ostensibly pose a threat to national security).

4 Third country nationals, with the exception of those belonging in 'vulnerable' groups, can also be expelled under Law 3907/2011, which implements the so-called Return Directive 2008/115/EC.
} 
evidence of an intention to commit such offences in Greek territory (this presumption is in application of Art. 96(b) of the 1990 Convention implementing the Schengen Agreement). Inclusion in the list creates the duty on the part of the third country national to leave the country within a deadline set by the executive. If she fails to do so, she may be subject to administrative expulsion.

Administrative expulsion can also be grounded directly in the third country national's criminal profile. According to Art. 76 of Law 3386/2005, those with custodial sentences of at least one year or with convictions for a range of serious offences independently of sentence, those who breach any of the provisions of Law 3386/2005 which have remained in force after the introduction of the ISIC, those whose presence in the country poses a risk to public order or national security, and those posing a risk to public health may be expelled by police order. The third country national can be held in remand, if deemed a flight risk or a threat to public order. She may raise objections to the decision before an administrative judge but this is not a formal criminal appellate procedure. There is also provision for an appeal before the executive, with a five-day deadline, which suspends the execution of the expulsion, but not the custodial, order.

Art. 83 of Law 3386/2005 makes it an offence for third country nationals to enter or exit the country or to attempt to do either without the appropriate documents (this is an independent attempt offence, not the inchoate offence of Art. 42 of the Greek Criminal Code). Note that being in the country without the appropriate legal documentation is not in itself an offence. It is also generally accepted (despite a small body of jurisprudence to the contrary) that the offence of entering is instantaneous and its actus reus is completed as soon as the third country national has entered or attempted to enter the territory. ${ }^{5}$ This means that the period of statutory barring begins at the time of completion of the offence, i.e. at the time of entering the country. Later arrests and prosecutions are therefore not in flagrante. In reality though, labelling the crime as instantaneous is meaningless because the administrative expulsion process trumps, both in law and in practice, criminal prosecution. A third country national, who has illegally entered or attempted to enter the country, can very simply be expelled by police order (recall that Art. 76 applies to those who have breached any of the provisions of the statute as well as other criminal offences). It follows that statutory temporal barring or the in flagrante rule do not apply and the dominant position is that there are no limits to when administrative expulsion can take place. A further very important upshot of the construction of the Art. 83 offence is that another party cannot be complicit to a third country national's presence in the country.

Indeed, the administrative expulsion process of Art. 76 potentially trumps, and in practice does indeed trump, every other way of governing the presence of

\footnotetext{
5 This is largely grounded on a Prosecutor's interpretative opinion (although these are not formally binding, they are persuasive sources of legal interpretation for courts) delivered in 1996 in the context of an earlier version of the same law (3216/1996 Opinion of the Public Prosecutor of Thessaloniki).
} 
third country nationals in the country. But even if one's case takes the criminal procedure route, criminal prosecution for the offences of Art. 83 can be waived and substituted by judicial expulsion on the order of a Public Prosecutor (who, in Greece, are members of the judiciary). The Prosecutor communicates her decision to the relevant police or coastguard authority in whatever suitable and expedient means, therefore by-passing the need for any formal notification, so that the third country national be immediately redirected or, should this not be immediately possible, that the expulsion process be commenced. Interestingly, much hangs on the interpretation of the immediacy requirement for the removal of the third country national if so ordered by a prosecutor who has decided to waive fullblown criminal prosecution. The removal can take place outside the in flagrante period (currently a maximum of 24 hours) to allow for contingencies such as transportation difficulties and so forth, so long as the state officials involved are not responsible, intentionally or negligently, for the delay.

Articles 29 and 30 of the ISIC present us with a different but exceptionally interesting case, because they do not criminalise third country nationals but rather Greek citizens or anyone else legally in the country. The offences introduced here are independent, that is not derivative of the offences committed by third country nationals outlined above.

Art. 29(6) conjunctively introduces a number of offences: i) facilitating the residence of a third country national in the country; ii) obstructing the police in a) tracking down, b) arresting, c) or expelling a third party national. Committing the offence for a profit is an aggravating circumstance. According to Art. 29(5) it is an offence to facilitate the a) entry into or b) exit from the country of a third country national who has not gone through the appropriate process (set in Art. 5 of the ISIC). Acting for a profit, professionally, habitually, or in collaboration with another or others are aggravating circumstances but do not have a bearing on the scope of application of the provision.

Art. 30 makes it an offence to transport third country nationals, who do not have the right to remain in Greece, either into, in, or out of the country and into another EU member state. The sentences range from 10 years in prison and a $€ 10,000-€ 30,000$ per person transported to life imprisonment and a fine of at least $€ 700,000$ per person transported depending on the presence of aggravating circumstances. The harsher sentences apply to traffickers but, as is the case in Art. 29 , whether the defendant is a trafficker or a smuggler or neither does not have a bearing on the scope of application of the offence. The offences are independent from the defendant's ulterior intent. ${ }^{6}$

\footnotetext{
${ }^{6}$ Art. 29 and 30 are linked to the so-called Facilitation Directive (2002/90/EC). For a detailed legal and moral analysis of the directive and related issues see R. Landry, 'The Humanitarian Smuggling of Refugees: Criminal Offence or Moral Obligation?’, Working Paper Series No.119, Refugee Studies Centre, University of Oxford, October 2016 (https://www.rsc.ox.ac.uk/publications/the2018humanitarian-smuggling2019-of-refugees-criminal-offence-or-moral-obligation). See also M. Provera, 'The Criminalisation of Irregular Migration in the European Union', CEPS Paper in Liberty and Security in Europe 80:1-48 (https://www.ceps.eu/publications/criminalisation-irregular-migrationeuropean-union).
} 
A 2015 amendment to the ISIC consolidated and slightly expanded the defences to the Art. 30 offences in a rather interesting way. The offences are not committed when the acts are performed while rescuing people at sea, when the person transported is one deserving of international protection, and, importantly, in order to facilitate the third country national's subjection to the legal process of assessing her status in order for them to be granted leave to remain and only if the police or the coastguard have been notified in advance. According to recent, though limited, first instance court jurisprudence the general necessity defence of Art. 25 of the Greek Criminal Code is not available to defendants under Art. 30.

\section{SOME EMERGING PATTERNS OF EXCLUSION}

We should now have sufficient information to single out some patterns of exclusion of third country nationals from the political community through the ways, in which they are treated as subjects of the Greek criminal law. I am hoping that what follows might also contribute to the framework of studying crimmigration practices across Europe.

\subsection{SELECTIVE INCLUSION IN AND EXCLUSION FROM THE CRIMINAL LAW}

At various turns third country nationals are treated by the law as criminally liable, in domestic criminal law or in other jurisdictions. Imputing criminal responsibility to them subsequently grounds their coercive treatment by the host state. This, however, is not accompanied by the increased protection that the criminal law typically affords defendants. Refusal of entry and expulsion decisions generally have to be properly grounded but they are either acts of the executive or acts of the judiciary which by-pass the penal procedure and defer competence to the executive to carry out the expulsion. This is so in all three broad categories of third country nationals without a right to remain in the country. The differences between these three categories relate to the degree of asymmetry between the third country nationals' penally relevant conduct and the consequences incurred.

(1) The criminal profile of those who already carry criminal convictions from outside Greece may ground refusal of entry or expulsion as a threat to public order or national security. The involvement in the criminal law abroad therefore serves to ground consequences brought about in Greece. This correlation of a criminal law infraction and certain consequences is generally governed by rules, which also typically provide a higher level of protection to the defendant. These rules, however, are not activated in this case, despite the obvious correlation between criminal responsibility and consequences. The issue here is not one of extra-territorial jurisdiction nor is it necessarily morally unthinkable for a state to 
hold one criminally responsible domestically for crimes committed elsewhere should these crimes have some impact within the state's territory (though this is not an argument that I can develop here). The problem is that a certain course of conduct serves as a justification for onerous consequences without this relation of imputation being governed by robust procedural and substantive rules. ${ }^{7}$

(2) This asymmetry is even further pronounced in the second case, namely of those who simply raise the suspicion of intending to commit criminal offences in Greece, on the basis of any past conduct, whether they have committed criminal offences elsewhere or not. Recall that entry refusal or expulsion decisions are based on criminally relevant behaviour. Once again, the problem here is not that this is necessarily ex ante criminalisation. It might not be altogether unjustifiable for a state to punish for manifest intentions if these have an external impact on the normative relations within the political community (this is again not an argument that can be developed here further). The problem is located in the asymmetry between the criminal law grounds for holding the third country national responsible and the subsequent treatment of the person as an administrative subject.

(3) Finally, the pattern of not affording third country nationals the protection that the criminal law, both substantive and procedural, generally makes available to defendants persists in the case of those who commit offences, either immigrationrelated or not, while already in Greece. This reaches its pinnacle in two moments. First, in the waiving of prosecution in favour of a prosecutorial expulsion order. What is defined in the law as a criminal offence is quickly turned into the administrative matter of processing the defendant. Secondly, in Art. 76(1)(c), which, reiterating the ubiquitous public order and security clause, gives the executive the freedom to override the requisite criminal procedure that accompanies the commission of a criminal offence and proceed to administrative expulsion on the vague terms of security, a freedom of which the executive makes ample use in practice. The subject of the criminal law is quickly transformed into an object of administrative law to be processed by the relevant authorities.

That the administrivisation of third country nationals leaves them at the mercy of often irrational and ungrounded decisions of the executive should be quite obvious. But it also exposes them to a subtler nexus of relative arbitrariness. Recall that, according to Art. 76 of Law 3386/2005, a third country national may be expelled if she has been handed a custodial sentence of a year or more. The key is what a one-year custodial sentence means. The Greek Criminal Code gives

\footnotetext{
7 This broadly mirrors a pattern identified by Catherine Dauvergne in relation to the intertwining between refugee law and international criminal law. Non-implication in international law offences is generally an admission requirement of asylum applicants in domestic jurisdictions. This comes with some added twists. First, the definition of political crimes, which would enjoy differential treatment in international criminal law, is tweaked in the context of refugee law so as to exclude from the outset any reasonable claims to political crime defences. Secondly, there is an asymmetry between the lengthy and resourceintensive procedure of international criminal law and the assessment of asylum applications. Thirdly, and relatedly, the fair trial provisions that apply to international criminal law do not apply to asylum procedures. See C. Dauvergne, 'The Troublesome Intersections of Refugee Law and Criminal Law' in The Borders of Punishment (K. Franko Aas and M. Bosworth eds.) (Oxford University Press 2013) pp.76-90.
} 
courts a great amount of discretion in sentencing. It is not uncommon for the prescribed penalty for misdemeanours to be imprisonment of a few months (the minimum is one month) and up to five years. Therefore, whether a third country national has been handed a prison sentence of one year might not have to do so much with the gravity of the offence she committed but rather with the particular court's disposition and sentencing practice. ${ }^{8}$

The administrivisation of the penal subject at times also leads to rather paradoxical results. The one-year custodial sentence expulsion cases again provide a useful example. Motivated mainly by prison decongestion concerns, the Criminal Code now makes the conversion of custodial sentences of up to five years to a fine almost a routine practice. This has rather interesting implications. Someone with a nominal one-year custodial sentence or longer might not serve any of it, because it is assumed that the offence is not considered serious enough to necessitate the sentence actually being served or because the offender is not considered likely to reoffend (if the offender does pose such a risk, then the conversion is not made available to her), but might still be expelled from the country on the assumption that she poses a threat to national security or public order simply because she is a third country national.

\subsection{THIRD COUNTRY NATIONAL STATUS AS THE ACTUS REUS OF CRIMINAL OFFENCES}

Greek law makes the citizenship status of third country nationals part of the actus reus elements of the offences of illegal entry or attempted entry in or exit or attempted exit from the country. If one with leave to remain performed exactly the same acts, they would of course not be committing a criminal offence. ${ }^{9}$

One might wonder why it might be remarkable that these offences include the status of the defendant in the actus reus. Alessandro Spena considers them to be manifestations of what he terms 'spurious' Täterstrafrecht, whereas the offence

\footnotetext{
${ }^{8}$ The range of penalties is currently under review by a criminal code reform committee but whether the current committee will succeed where its numerous predecessors have failed and whether a new code will be in fact be enacted remains to be seen.

${ }^{9}$ Citizenship status and actus reus are intermingled in other ways too across Europe. Let me draw a parallel to two characteristic examples. In some cases that an offence is being committed within the context of the process of immigration control, either by third country nationals or not, either renders the offence a delictum sui generis and/or aggravates it. For example, s.3 of the UK Borders Act makes assaulting immigration officers a specific offence incurring a heftier penalty than the basic s.39 assault of the Offences Against the Person Act 1861. To form a complete picture, one should also consider practices, in which a defendant's status as a third country national might not be written into the law but guides the enforcement of the relevant rules. A very representative example comes from Sweden. As Vanessa Barker shows, there is a pattern of third country nationals who beg or engage in other 'vagrant' activities to be involved in the criminal justice system rather than be afforded the provisions of the welfare state. Very interestingly, this practice is premised on a rhetoric of dignity and protection of the defendant as well as, indirectly, the community as a whole from the indignity of begging. This is why Barker intriguingly dubs it 'benevolent violence'. V. Barker, Nordic vagabonds: The Roma and the logic of benevolent violence in the Swedish welfare state, European Journal of Criminology (2017) 14/1 pp.120-139.
} 
ostensibly targets the defendant's actions, in reality it targets the defendants themselves, who are considered dangerous or essentially criminal precisely because of their status or one of its aspects. ${ }^{10}$ Spena's claim is that criminalising the actor rather than the action is at odds with the point of the criminal law. Although this critical claim is correct, it is not entirely clear that the case of offences determined by one's citizenship status really are instances of Täterstrafrecht, spurious or otherwise. This would be the case if the inculpating element were an innate characteristic of the defendant. It is, however, obviously not uncommon for the criminal law to make a contingent, institutional feature of the defendant's identity an element of an offence. The question then would be whether it is permissible to criminalise a certain act that could not have been committed had the defendant not borne that specific characteristic. This is a substantive and context-sensitive question, the answer to which does not depend on the form of the offence.

There are, however, two other, interrelated noteworthy things about offences of this sort. First, one's status as a third country national without leave to remain is negative; it indicates a characteristic that one does not have. For it to become a positive legal status, a legal instrument must regulate it. Criminal laws which make illegal entry without the appropriate documents are such instruments. In other words, one's status as a third country national is determined, at least partly, by the prohibition of entering the country. Therefore, the offence both creates its subject and authorises the subject's coercive treatment when the criminal law is meant coercively to regulate activities, which are possible independently from their regulation by the criminal law. This is different to the question of the permissibility of criminalising mala probibita. That concerns a certain conduct's wrongfulness, whereas in the case at hand, it is a matter regarding the very conditions of possibility of the action. Nor should it be confused with omissions liability, for the obvious reason that it is not within the third country national's control to obtain leave to remain. Her citizenship status is determined by the criminal law as soon as she attempts to enter the country.

The second related point is a normative extension of the first one and I will discuss it later under section 5.1 .

\subsection{THIRD COUNTRY NATIONALS ALWAYS STRANDED AT THE BORDER}

Earlier on I tentatively introduced a distinction between third country nationals at the border and after having crossed it. It is now clear, however, that this distinction may hold in physical terms but, when it comes to their normative standing for the purposes of the criminal law, third country nationals always remain at the border.

Recall some of the penally relevant regulation of third country nationals: their entry and continued presence in the country depends on their criminal profile;

\footnotetext{
${ }^{10}$ A. Spena, Iniuria Migrandi: Criminalization of Immigrants and the Basic Principles of the Criminal Law, Criminal Law and Pbilosophy (2014) 8, pp.635-657.
} 
entering into or exiting the country illegally is an offence; crucially, their presence in the country is not independently criminalised; they are not treated as accomplices in the accommodation and transportation offences of Articles 29 and 30 .

There might have been two possibilities of recognising the normative presence of third country nationals in the country. The first would be through the instantaneous character of the offence of illegal entry. It could have been the case that the third country national commits an instantaneous crime entering the country but then gradually enters the political community as a subject of the law. The rest of the structure of related provisions, however, undermine this opportunity. Transforming the offence into an administrative matter through the expulsion process of Art. 76, waiving prosecution, prolonging the timeframe of judicial expulsion beyond the in flagrante period, contribute to keeping the third country national in the limbo of rightlessness at the border.

The second way would be if they committed a different criminal offence while in Greece, in which case they would be afforded the protection of criminal procedure and the criminal justice system at large. Even this recognition through the exclusion of punishment, however, is not afforded to third country nationals in the way that is afforded to citizens. The commission of any criminal offence can, and routinely does, result in their administrative expulsion from the country. Therefore, violations of the criminal law on their part are only disruptions by someone who has no normative position in Greece. Their labelling as criminal offenders is only nominal.

Another way of looking at this is in terms of how the law cuts across the dimensions of existence of the third country nationals. Physically they are in the country. Their spatial dimension, however, is severed from their temporality, which is substituted by and subsumed under the structure of legal provisions grounding them at the threshold. The application of legal judgment to real world facts always presupposes a suspension of the latter's temporality. Criminal responsibility, for example, can only be apportioned with reference to an isolated temporal fragment; expand the timeframe and radical indeterminacy ensues because of the proliferation of causal relations between events and because of the increasing complexity of the psychological attitudes, which would constitute the defendant's mens rea. For it to be grounded, punishment must also assume the image of the defendant at the time of commission of the offence. In the case of all other criminal offences, however, this reduction of time to legal judgment, although detrimental, as is every instance of reduction, does not eradicate the offender's legal personality. It transforms it in significant respects but it does not deprive the offender of all normative membership in the political community. In the case of third country nationals, however, the judgment of the criminal law governs the entirety of their presence in Greece; their wrong is trying to enter the country and the response to this wrong is expulsion. This precludes every other 
instance of normative participation in the political community and its institutional structure. As legal subjects, third country nationals are always at the border.

\subsection{THIRD COUNTRY NATIONALS EXCLUDED FROM THE CRIMINAL LAW ALTOGETHER}

So far, I have highlighted the differential treatment of third country nationals as special subjects of the criminal law and the instrumental role that the criminal law plays in keeping third country nationals always at the border denying them membership of the political community. I will now turn to a pattern, which is even more worrying: third country nationals are altogether excluded from the ambit of the criminal law.

There is a worrying trend developing in Europe and elsewhere; a trend of making third country nationals the objects of the criminal law but not its subjects. Mitsilegas gives a detailed survey of practices of employing domestic criminal law in order to prevent third country nationals even reaching the borders of European states. This is done mainly through legislation, which targets traffickers and smugglers rather than third country nationals themselves. ${ }^{11}$

But the pattern seems to be reaching the border too. Let us consider the offences of Articles 29 and 30 a little more closely. A central element of the actus reus is the very status of the person transported. Had the third country nationals been Greek or EU citizens or had other leave to be in the country, the acts of providing or transportation would have been innocent; indeed, admirable acts of hospitality. The third country nationals' citizenship status makes the very interaction with them in a non-harmful manner a criminal offence. The wrong is thus displaced from the actions of the defendant themselves to features of the object of the offence.

The primary (but not sole) targets of these offences are traffickers and smugglers. What is striking, however, is that on the construction of the offences their actions are not wrong because they exploit and endanger other human beings but because they facilitate the entry with people who do not have right of access to a territory. Third country nationals are therefore not constructed even as proper victims of the offence in the criminal law sense. Sure enough, there are other provisions for victims of trafficking. Art. 19A of the ISIC provides that victims of trafficking or a number of other offences may, for 'humanitarian reasons' be granted leave to remain, which is, however, temporary (one year in the first instance) and heavily conditioned. Article 49 grants trafficking and smuggling victims a three-month period of 'deliberation' for them to overcome the trauma of their experience, an affordance which can be withdrawn should it transpire that the victim has rekindled her relations with the traffickers/smugglers or, yet again, 'for reasons of public order and security'. Therefore, even the recognition of third

${ }^{11}$ V. Mitsilegas, The Criminalisation of Migration in Europe: Challenges for Human Rights and the Rule of Law (Springer 2015). 
country nationals as victims keeps them outside the realm of the criminal law. It is an administratively organised act of charity. Charity is an unequal relationship par excellence not only because of the inequality of resources between the charitable person and the subject of her philanthropy but also, and perhaps primarily, because the latter does not participate in the determination of the norms justifying and defining the charitable act. Recognising victims as the objects of charity again prevents third country nationals from being fully-fledged legal subjects of the law and therefore excludes them from membership of the political community.

At the same time, the opportunity that citizens have to associate normatively with third country nationals is curtailed. Recall that the presence in the country without leave is not in itself a criminal offence. This means that one cannot be complicit to an offence committed by a third country national committed by being in the country. Combine this with the fact that Art. 29 and 30 offences are dissociated from the illegal entry offences and the clear line that separates citizens from non-citizens is revealed.

This normative separation has another important ramification. The radical exclusion from the criminal law goes even deeper, because it ruptures social and political relations. As the offences of Articles 29 and 30 are not sensitive to the motivation of the defendant, they apply not only to traffickers and smugglers but also to anyone performing the acts in question. This, of course, includes volunteers, of whom there have been thousands, who provide assistance to third country nationals motivated by a sense of solidarity. This is not only a theoretical possibility; volunteers have in fact been prosecuted in mid-January 2016 five volunteers, members of NGOs were arrested and subsequently prosecuted for towing ashore refugees struggling in plastic dinghies off the coast of the Greek island of Lesvos. Similarly, in the summer of 2015 more volunteers were prosecuted for transporting refugees inland (these did not lead to convictions). ${ }^{12}$

So, the parties in these relations find themselves in an impossible tension between different ways of relating to each other. Simply being in a certain place at a certain time reduces third country nationals to a miasma, and it is a crimen/крí $\mu \alpha$, a sin for citizens to interact with them. The latter are treated by the criminal law in a way that undercuts their social relations with third country nationals. This penetration of the criminal law into social relations usually meets its limits at the point of harm or, at any rate, some manifest wrongfulness. Here, however, the overlap is complete. Citizens are faced with incompatible sets of reasons for acting towards third country nationals and their motivational disposition is similarly torn in two.

This culminates in the defence available to those prosecuted under Art. 30. Recall that one does not commit the offence, if one aims at facilitating the

12 Note that arrests and prosecutions continued even after the introduction of the defences in 2015 . The Greek Ombudsman has intervened on the matter: http://www.synigoros.gr/resources/150727-stp.pdf (in Greek). 
subjection of the third country national to the appropriate process of registration, asylum application and so forth. Volunteers are thus justified to interact with third country national only if they act as proxies of the state and participate in the rendering of the objects of the offence into administrative subjects-objects. The defence does not restore the possibility of social relations developing between those with leave to remain and those without; on the contrary, it deepens the rift because it makes citizens complicit to the administrativisation of the existence of third country nationals and their exclusion from the political community.

\section{WHAT IS WRONG WITH 'CRIMMIGRATION' PRACTICES?}

The analysis so far has been largely diagnostic, singling out some ways in which third country nationals are treated in Greece largely as a result of implementing EU law requirements. I have also suggested that these patterns are different and mutually complementary ways of marginalising third country nationals and excluding them from the political community of the host state.

However, I have so far not touched upon the question of justification. Why do we have reason to believe that it is impossible to ground the differential treatment and marginalisation of third country nationals?

\subsection{External CRitique}

One could engage in external institutional critique in that one could find inconsistencies with obligations that states have towards non-citizens on the basis of international law and human rights. Such objections are of course important and could make a great deal of difference but I leave them to one side. International promise-based commitments are extremely fragile and easy to renege on both formally and in practice. The way, in which refugees have been treated in Europe since 2015, and especially the return agreement with Turkey, is the most recent indication of this. I therefore consider it a more challenging and pressing problem to find constraints to how a state can treat third country nationals drawn from within the constitutive conditions of the political community, which the state represents. More specifically, I want to explore whether any constraints to the penal treatment of third country nationals can be drawn from the logic of the criminal law itself. 


\subsection{THE ARGUMENT FROM WRONGFUL CRIMINALISATION}

Some take issue with immigration-related offences themselves. For example, Ana Aliverti believes that the very terms of criminalisation are problematic. ${ }^{13}$ The majority of such offences are offences of possession (primarily of counterfeit documents); omission (e.g. not being in possession of appropriate documents, failing to cooperate with immigration authorities etc.); status (being in the territory of the host state); strict liability; low harm levels (abstract endangerment is often resorted too as justification for such crimes). These are reflected in Greek legislation as well; both in the offences that I have outlined as well as others, which I left undiscussed. The objection is along the lines of the general argument against such offences: the threshold of criminalisation is too low. ${ }^{14}$

I will not discuss the substance of the argument from wrongful criminalisation, because I think there is a prior issue with the argument's very character that does not allow it to get of the ground as a general critique of crimmigration practices. The claim that criminal offences lower the threshold of criminalisation by relaxing either the act and/or fault requirements already presupposes a general conception of wrongfulness. Such a conception, however, will inevitably be controversial and therefore extremely vulnerable to external critique. To illustrate, Aliverti seems to assume that causing harm to others is generally a minimum condition of criminalisation. Clearly, further, external argument is required for compelling one to accept this. It follows that one also does not have compelling reason to accept the accompanying critique of crimmigration. For example, suppose that we think of penally relevant wrongs not in terms of harm but rather as the unauthorised interference or domination. This already significantly widens the scope of criminalisation in a way that might permit a larger number of inchoate crimes or even offences with minimal act and fault requirements on the condition that they are wrongful because they interfere with the liberty of others in one way or another.

Alternatively, the scope of the wrongful criminalisation claim might be narrower and only apply to specific jurisdictions. This might be a more promising reading, because the argument can be possibly measured up against a specific institutional structure in light of the systemic requirement of normative coherence. But the mess of institutional reality, which allows for a wide range of possible reconstructions makes even this so controversial as to leave the debate inconclusive. Moreover, such a jurisdiction by jurisdiction reconstructive approach would not allow us to articulate a general critical argument with a wider scope of applicability.

13 A. Aliverti, 'The Wrongs of Unlawful Immigration', Criminal Law and Pbilosophy online first publication doi:10.1007/s11572-015-9377-y (2015).

${ }^{14}$ Lucia Zedner raises similar points: L. Zedner, 'Is the Criminal Law Only for Citizens? A Problem at the Borders of Punishment', in Franko Aas and Bosworth (n 5), pp.40-57. 


\subsection{DOES CRIMMigRATION REVEAL A PATHOLOGY OF LIBERAL DEMOCRACIES?}

Some think that the differential treatment of third country nationals reveals a much deeper, and irremediable, problem. It is the state's prerogative, the argument would go, to reserve certain protections for its citizens or, at any rate, for those to whom the state has granted membership rights, and treat others as outsiders. This is because citizenship is a necessary threshold requirement for one's participation in the political community as a bearer of rights. This not only makes non-citizens vulnerable to being treated differentially by the state but it also helps to reaffirm the closure of the political community and to strengthen the bonds that constitute it. Vanessa Barker thinks that this exclusionary tendency of modern liberal democracy finds its pinnacle in the case of deportations:

The deportation of criminal aliens dramatically captures the paradox of democracy. The reason a criminal alien is deported is because of his or her alienage, because of his or her status as a non-citizen. Citizens who commit the same crime and serve the same time in the criminal justice system are not then subject to deportation; this sanction is reserved for non-nationals. Deportation, or expulsion, is one of the most extreme forms of state power the state effectively cuts off all ties, connection, and any obligation to the person: deportation is a kind of civic death. ${ }^{15}$

This is ostensibly what the appeals to the rhetoric of security and order, which, as I have highlighted, abound in European and Greek law, reflect. Third country nationals who are implicated in the commission of criminal offences purportedly pose a threat to the cohesion of the political community of the host state because they disrupt its peaceful functioning. It is not entirely clear why this argument would hold citizens who violate the criminal law to not pose the same threat. Presumably the answer would go along the following lines. Citizens have accepted the values of the political community that the criminal law entrenches and enforces. Violation of the criminal law by citizens is therefore considered exceptional; enforcement and punishment restores the previous order of generalised acceptance. Non-citizens, on the other hand, have not displayed the same commitment to the values animating the political community and their criminal transgressions manifest a default, hostile disposition towards these values. In this picture, Feindstrafrecht ${ }^{16}$ appears not only as a justified employment of the criminal law but as an inevitability. Its scope also becomes much wider; it is not only those who express radical animosity against a state that are the enemies but potentially every non-citizen.

\footnotetext{
15 V. Barker, 'Democracy and Deportation: Why Membership Matters Most', in Franko Aas and Bosworth (n 7) pp. 237-254.

${ }^{16} \mathrm{G}$ Jakobs, 'Selbstverständnis der Strafrechtswissenschaft vor den Herausforderungen der Gegenwart (Kommentar)' in A Eser, W Hassemer, and B Burkhardt (eds), Die deutsche Strafrechtswissenschaft vor der Jahrtausendwende (C.H.Beck 2000).
} 
Lucia Zedner believes that the inescapable exclusionary force exerted by citizenship-based democracy also reveals a serious limitation of theories, which take a public law/political approach to the grounding of the criminal law. ${ }^{17}$ If the criterion of publicity, which determines the conditions of criminalisation, criminal responsibility, as well as the limits of punishment, is so closely associated with membership qua citizenship, it necessarily follows that it is permissible for the state to use the harsh treatment that the criminal law authorises to exclude non-citizens from the political community.

This type of argument goes to the heart of the matter to the extent that it places the problem in the very conditions of operation of modern states. However, I believe that the critique is for the most part misplaced. It is the case that the criminal law governing third country nationals employs the rhetoric of exclusion but it does so at the price of incoherence. This is what I will argue in the following section.

\section{THE INCOHERENCE OF CRIMMIGRATION PRACTICES}

Spena sees the exclusiveness of the criminal law, with emphasis on offences of illegal immigration, as animated by the metaphor of the home:

The wrongness of \{irregular migration\} might be conceived accordingly, as a kind of trespass into the territory of states - and thus, metaphorically, into each citizen's home; something like an attack on the citizens' right to exclude unwanted strangers from their homes, as though irregular immigrants (and, more generally, "irregular enterers") violated the citizens' "common home". 18

He then goes on to argue that the metaphor collapses as soon as it is raised, because it rests on the false assumption that national territory can be represented in terms of a private sphere, which enjoys protection against trespass. Spena's objection to this assumption is that the territory of the state is valuable because it serves public interests and enables public relationships. The character of the territory of the state is therefore not to be conflated with the inviolable private sphere of individuals, which the home represents. Nor, Spena continues, can the territory of the state be plausibly thought of as the state's property.

Although the general orientation of Spena's critique is correct, I think that it overemphasises the home metaphor. The justified exclusion claim is not based on

\footnotetext{
17 Zedner (n 14).

18 A. Spena, 'A Just Criminalization of Irregular Immigration: Is It Possible?', Criminal Law and Philosophy, online pre-publication DOI 10.1007/s11572-015-9375-0 (2015).
} 
the assumption that illegal immigration is a crime of trespass but rather that the migrant forces her way in an unauthorised manner into a political community, of which she is not a member, while at the same time engaging in normative interactions within the domain of the state. And it is this unwarranted interaction that ostensibly justifies exclusion.

I would suggest that a critique of crimmigration practices must distinguish between three stages of implicating third country nationals in the criminal law, which are often conflated. I will examine these in turn putting more emphasis on the first stage, which is where the most pressing problem in fact emerges. It should also be noted that the arguments in this section apply to all citizens. Nevertheless, I will continue to focus on those without leave to remain, as their case poses the most difficult questions.

\subsection{DifFERENTIAL TREATMENT AFTER CRIMINALISATION}

As we saw above, the justified exclusion claim, which many attribute to modern liberal democracies as well as to political theories of the criminal law, assumes that citizenship is a necessary threshold requirement of being treated in a certain way by the law generally and the criminal law in particular. This entails a view of citizenship as a state of being. In doing so, it takes as true the familiar counterfactual that informs much of the social contract tradition of the transition from the state of nature to a rightful condition of political belonging to be the way in which participation rights are in fact awarded. In this image, there is a moment in each legal subject's life at which citizenship is conferred resulting in awarding the new citizen a full bundle of rights and imposing the accompanying duties.

This view also entails an assumption regarding the criminal law, an assumption that is not uncommon in criminal law theory. Namely, it assumes that the criminal law stands out from the rest of the legal/institutional structure. Whereas other areas of law, the assumption would go, empower people to enter certain relations therefore affirming their status as members of the political community, the criminal law's aim is to exclude people.

Let me start with the assumption regarding the nature of citizenship. The sense of citizenship that is relevant in this context is one that refers to what determines the normative position of a person within a legally constituted territory; her rights and duties in relation to others in the political community as well as the state, which institutionally represents the collective. One way of gaining normative access to the community is of course by being conferred the status of citizenship either by birth or acquisition. However, to consider this static conception of citizenship as the only way of becoming a member of the political community seems entirely at odds with how normative participation in modern states works especially in contemporary circumstances of increased inter-state mobility and intra-state pluralism. Rather than as a status, citizenship is best understood as a constant process of normative interacting - often a process that never reaches the state of being a citizen. It depends not necessarily on an originary 
and ceremonial moment of status conferral but, all too frequently, on the web of normative interactions of the individual with the political community. It is therefore necessarily multi-layered and variegated. How narrow or wide the scope of membership of the political community (which I consider a more appropriate term than citizenship) is depends on the entailments of implicating an agent in the law in a certain way.

Therefore, when trying to determine how one may permissibly be treated by the criminal law, the question becomes from is one a citizen so as to be the proper subject of the criminal law?' to 'what does implicating the agent in the criminal law presuppose and what are its necessary upshots?'.

I would suggest that being implicated in the criminal law has two general entailments, which are independent from the substantive aims that a criminal law system might pursue.

The first entailment is that the subject of the criminal law is normatively capable of committing a criminal offence. This is broken down further. On a very basic level it means that that one has the bare capacity to act and to form certain intentional states. But more is required for an act or a failure to act to count specifically as a criminal offence. This entails that the agent is under certain duties to others, duties which are specifically legal, and that one commits a criminal offence as the subject of the criminal law. Suppose that some of these duties, such as the duty not to assault or cause the death of others, might be reflections in the law of duties, which everyone owes to others independently of the law. Be that as it may, no sooner are they institutionalised in law that they become specifically legal. Other duties will be more pervasively institutional. Some offences can only be committed by those who have been ascribed a certain institutional role. Such examples can be drawn from across the criminal law but, to stay in the context of immigration offences, take Art. 27 (1) and (4) of the Greek ISIC, according to which it is a disciplinary and criminal offence for civil servants to provide services to third country nationals who lack the appropriate documentation.

The same can be the case in whole schemes of legal regulation. Consider the example of property offences generally. One can only commit a property offence if property relations are institutionalised in a way that makes certain interferences with others' property a violation of a duty. Interferences with property offences are typically assumptions of property rights. Now, imagine someone who, by law, has been excluded from the law of property altogether; she may not own, possess and so forth. It will be impossible for that person to commit a property offence because it is institutionally impossible for her to assume property rights. She might be performing the physical act on which the assumption of the property right supervenes but she will not be committing the offence of assuming the property rights.

The second general and necessary entailment is that punishment is authorised by the criminal law as a response to a violation of specifically legal duties by subjects of the criminal law, which, as I argued above, necessarily amounts to 
being a citizen in the sense that one's normative position is determined by a web of laws that is wider than the criminal law. Seen from the opposite perspective, the violation of a criminal law-related and -enforced duty triggers an obligation on the part of the offender to act or forebear in the way, in which the state's response requires him to. It follows that punishment is meted out in the offender's capacity as a subject of the law and that it must be such that can be served by subjects of the law.

Let us now move from this admittedly high level of abstraction to some concrete examples drawn from the earlier discussion, which illustrate the incoherence of crimmigration legislation.

As we saw, Greek (and European) law authorises the administrative expulsion of third country nationals who have committed offences either abroad or in Greece as well as the waiving of criminal prosecution and expulsion of third country nationals who have committed offences in the country. Expulsion from the country amounts to stripping the offender of her legal subjectivity altogether, because it makes it impossible for her to interact in a normatively/legally significant way with the political community of the country, in which the offence was committed. If my argument that it is a necessary entailment of treating people through the criminal law that punishment be meted out to offenders as subjects of the criminal law is correct, then it becomes immediately clear that expelling offenders for having committed a criminal offence is incoherent. ${ }^{19}$ Although the content of punishment can only be determined substantively and not by the formal requirements of the criminal law, it has to be such that it can be served by a proper subject of the criminal law.

This is clearly the case when one is punished for crimes committed in the country. But how about those who are expelled because they have committed criminal offences abroad or only pose a risk of committing an offence in the host country? Does it make a difference that an offence has not been committed domestically? I would suggest that it does not. In responding by expelling the third country national either for offences committed abroad or for posing a threat of offending domestically, the municipal jurisdiction already implicitly accepts that the third country national is under some domestic criminal law related duties, the possible violation of which may incur punishment. As I argued earlier, to recognise one as bearer of such duties amounts to recognising one as a proper subject of the (criminal) law, who must therefore be treated accordingly.

This already points to a fundamental problem with the all too common invocation of public order and national security, which ostensibly authorise the differential treatment of third country national as independent reasons. No sooner

\footnotetext{
${ }^{19}$ Note that there might also be independent, concurring reasons drawn from one's conception of the aims of punishment, for which expulsion-as-punishment is incoherent. Say, for example, that you are a retributivist who thinks that punishment somehow 'undoes' the wrong, which would otherwise stay in the community. It is hard to see how this 'undoing' of the wrong can happen outside the community. Or suppose you are a full-blown consequentialist about punishment. It is again difficult to see how the good consequences you might want to achieve will be achieved by all but relinquishing control over an offender's actions by expelling her from the country leaving open the actual possibility of her return.
} 
are security and order ascribed the character of legal reasons (which they are because of their inclusion in legislation as legal premises) for treating one in a certain way that a series of implications surfaces. The threat to security and order that one supposedly poses can only be a threat to disrupt the legal normative order that frames the political community by violating its norms. This already presupposes that the third country national is the proper subject of the law because only subjects of the law, and therefore members of the political community / citizens to one or another degree, have the normative capacity of violating the law in a way that undermines order and security. It follows that they must be treated as bearers of this normative capacity. This does not stop a government from in fact taking extra-legal measures against third country nationals or others in the name of security and order, i.e. measures which are not grounded in law at all. But it should be abundantly clear that such measures are complete departures from the legal order and that the state then operates not as a state any longer, not as the institutional structure that instantiates the political community, but rather as a private, and unhinged, agent acting on force alone rather than on authority.

One possible response to this objection of incoherence might the substantive argument at which I hinted earlier. It might be that the reason for the exclusion is that there is no place in the political community for someone who has breached certain rules which are held to be of particular moral significance to such an extent that they constitute an admission threshold. One might draw a parallel to rules of associations: to be a member of the association, one must respect its rules; if one fails to do so, the association is at liberty to end the membership status of the violator of the rules. ${ }^{20}$

The question then is what kind of person is accepted in a modern, broadly liberal, legally constituted political community. Associations might be constituted by specific values or goals, which its members are expected to endorse with the violation of the association's rules raising a presumption of non-endorsement and therefore non-belonging. In contrast, the subject of the criminal law of a modern, liberal state is precisely the person who does not offer, and is not expected to offer, any guarantees that she will endorse or even not violate the rules that apply to her. The subject of the criminal law has the ability to develop desires and motivations, the reasoning ability to accept that she is under certain enforceable duties to others, and the ability to understand and accept that she will be justifiably be held accountable should she fail to discharge these duties.

Of course, none of this is to say that the criminal law does not exclude offenders to some degree. Quite obviously, those with convictions are excluded from the exercise of some rights and the enjoyment of some resources, which would have otherwise been available to them. The correct way of making sense of this is as a, presumably justified, transformation of the normative position of the

${ }^{20} \mathrm{I}$ am grateful to Antony Duff for prompting me to think about this point in these terms. 
person in the political community. This transformation, by incarceration, fine or whatever other punitive practice might be available in a political community, also generates some duties on the part of the state. Suppose, for example, that the point of a custodial sentence is deprivation of freedom. This means that the state is under an obligation to ensure that no other burden will be imposed on the offender either during the period of incarceration as well as post-sentence. Those who have been deprived of their liberty as a response to their criminal wrongdoing must be given the chance fully to reintegrate in the political community postpunishment.

Speaking of stateless people Hannah Arendt observes in passing in The Origins of Totalitarianism:

The best criterion by which to decide whether someone has been forced outside the pale of the law is to ask if he would benefit by committing a crime. If a small burglary is likely to improve his legal position, at least temporarily, one may be sure he has been deprived of human rights. For then a criminal offense becomes the best opportunity to regain some kind of human equality, even it is be as a recognized exception to the norm. ${ }^{21}$

The implications of Arendt's dictum are now fully revealed. Becoming a proper subject of the criminal law amounts to more than being ostracised; it means remaining a member of the political community albeit with a different normative standing in it.

So, total exclusion through expulsion is incoherent but this still leaves us with a state treating third country nationals differentially short of expelling them. What if, for example, a state excluded third country national defendants from the procedural guarantees reserved for citizens such as the exclusion from appellate procedures?22 The problem here is one of internal consistency. One becomes implicated in the criminal law because and only because one has failed to discharge duties to which one is subject. This means that differentiation between citizens and third country nationals in the way they are treated by the criminal law for the same offences is grounded on something other than the offence committed. This, however, is unjustifiable. This is so, even if the citizenship status of the defendant is included as a circumstance of the offence. Things would be different only if that status were part of the wrongfulness of the offence.

This brings us to offences, which can only be committed by a third country national, i.e. cases in which the nationality status of the defendant is included in the actus reus of the offence. The criminalisation of entry or attempted entry without the appropriate documents is such an example. I have already said that there is already an incoherence in bringing into being and punishing the subject at one and the same time. The deeper normative implication of this is that such

\footnotetext{
${ }^{21}$ H. Arendt, The Origins of Totalitarianism (Harvest 1973) p.286.

22 Once again, I put to aside constraints from human rights and the Rule of Law to focus on the constraints imposed by treating people as proper subjects of the criminal law.
} 
offences include the third country national as a member of the political community by making her the proper subject of the criminal law and at the same time punish her for not being a member of the political community. Spena argues that such offences, which are mala probibita, fail to provide defendants any contentindependent reasons for complying with the prohibitions. ${ }^{23}$ If, however, we think of citizenship qua layered membership of the political community in terms of the web of rules to which one is subject, then we will see that third country nationals do have content-independent reasons to follow criminal law that apply to them. The problem here is substantive -and it is the normative extensions of the crimmigration laws in question creating their subjects only to punish her (section 3.2 above). Offences which include the defendant's citizenship status in the actus reus are, first, impossible to comply with, because they simultaneously include the third country national in the political community as the proper subject of the criminal law and punish her precisely for not being a member of the political community.

The discussion so far should have also addressed the second assumption in much of the critique of crimmigration practices but also in much of criminal law theory generally, namely that the criminal law is an outlier in the legal system because it is an instrument of exclusion as opposed to other legal domains, which provide different channels of normative inclusion in the political community. This penal exceptionalism collapses as soon as we realise both that the subject of the criminal law is determined as such by the way in which she is shaped as a legal subject by other fields of law and that the determination of one's normative position as a subject of the criminal law necessarily re-shapes one's normative position in other legal fields.

\subsection{THE PERMISSIBILITY OF IMPLICATING THIRD COUNTRY NATIONALS IN THE CRIMINAL LAW}

So far I have discussed the implications of in fact involving a third country national in domestic criminal law. I have rejected the view that the coercive exclusion of aliens through the criminal law is an inevitable trait of modern liberal democracies arguing instead that it reveals a deep inconsistency with the very terms of operation of such legal systems.

The next question is why it is permissible for the host state to implicate a third country national in its criminal law. In the real world this is a moot point. Legal systems typically and extensively do govern the lives of aliens by the criminal law and the first priority for theory should be to work out the implications of this, as I tried to do in the previous section.

It is also the case that in a world that is increasingly legally interconnected, through various instruments such as human rights, international law and so forth,

23 Spena (n 18) 
one is always to one or another extent subject to domestic legal systems. This already triggers the normative chain reaction, which I tried to describe earlier, thus authorising domestic jurisdictions to govern the lives of those who do not have full citizenship status.

Nevertheless, suppose counterfactually that one is not the subject of domestic law at all. If the conception of membership of the political community is multilayered and incremental as I argued above and if it depends on one actually being implicated in the legal system rather than necessarily on some other originary moment or a fact, then one's presence in a country's territory alone does not suffice for one to become a subject of the law and gradually a member of the political community. It follows that implicating one in the criminal law seems like a unilateral coercive act. ${ }^{24}$

In an admittedly very cursory way, I would suggest that the answer that best coheres with the rest of the argument in this article is an implicit consent-based one. Some might believe that this consent is assumed to have been offered by the third country national simply by her presence in the country. I do not think this to be the case. In-line with what I have been arguing so far, I do not consider mere physical presence and interference with the brute facts, on which the criminal law might supervene, sufficient for one to become a subject of the criminal law. Such subjection must be normative from the outset. Such a normative connection, and therefore an implicit consent to be subjected to the criminal law, is provided by a third country national's acting in the host country in a way that manifests an intention to exercise rights, which would only be available to her had she been a subject of the legal system of the host country. Engaging in relations, which require normative membership status, relations pertaining, for example, to employment or property, signify a voluntary subjection to the normative web governing these relations. The criminal law is an inextricable part of this web.

A second reason for which it is permissible for a state to subject a non-citizen to the criminal law is that interference with brute facts, which would have constituted a criminal offence have an impact on the normative standing of the victim in relation to other members of the political community. I will develop this argument further in the following section.

\subsection{THE NECESSITY OF TREATING THIRD COUNTRY NATIONALS AS THE PROPER SUBJECTS OF THE CRIMINAL LAW}

Whereas whether it is permissible for a state to involve non-citizens in the criminal law is of secondary significance in light of actual state practices, the question whether such involvement is necessary seems to be acquiring a new importance. As I pointed out in the earlier discussion, there are worrying signs that states tend

\footnotetext{
${ }^{24}$ It should also be noted that the problem also haunts conceptions of the criminal law according to which the only threshold condition of criminalisation and punishment is moral wrongdoing, because even this requires a supplementary account of the jurisdiction of a state to criminalise and punish.
} 
to exclude aliens from the criminal law as a way of excluding them from the political community altogether.

Arguably the most interesting and promising attempt at reconciling a citizenship-based account of the criminal law with a duty to include third country nationals in the criminal law as its proper subjects has been offered by Antony Duff. ${ }^{25}$ Duff proposes that we consider non-citizens as guests, who, like all guests, are both protected and bound by the rules governing the host country. They are bound by these rules either because they incorporate universal duties, which apply to the guest anyway or out of respect for the modus vivendi of the host community. But they also ought to be protected as victims of crime:

The more important point concerns responses to wrongdoing: a decent polity will count and treat wrongs committed within its borders against visitors as no less public, no less wrongful, than wrongs committed against citizens. Not only should we not wrong guests: if a guest in our home is wronged, that is our business; and whilst there are dangers that citizens will not take wrongs against visitors as seriously as they take wrongs against citizens ("She was only a tourist"), members of a civilized polity will not discriminate in this way. ${ }^{26}$

The key thesis here is not that a state has the authority to punish because of the universality of some duties owed by everyone to everyone else but because of the guest status of non-citizens and the hospitality that the host state owes to noncitizens. The question then is what generates these duties of hospitality.

One possibility is that they are agent-dependent duties, in that states voluntarily take them on and are motivated by them. Suppose that this is the case leaving to one side the question of how collective intentions, goals, and commitments might be formed. As Zedner points out in objection to Duff, the substantive problem is that the whole argument would rely exclusively on the good will, so to speak, of states and we would be rather hard-pressed to find such good will especially, I would add, at a historical juncture where more and more states in fact display increased hostility against aliens.

Alternatively, duties of hospitality are agent-independent and derived from some kind of universal normative order. Absent a global institutionalised rightful condition, duties of protection towards aliens, and the respective duties on aliens' part, might be grounded in something which we might term solidarity or something similar. I have no doubt that a plausible argument along these lines can be made. Nevertheless, the scope and inevitably contested nature of such arguments makes it doubtful that they can be serviceable in real contexts, in which

25 R.A. Duff, Responsibility, Citizenship, and Criminal Law, in R.A. Duff and S.P. Green (eds), The Pbilosophical Foundations of the Criminal Law (Oxford: Oxford University Press 2011).

${ }^{26}$ Ibid. 142. 
real people are in fact stranded at the border and treated as administrative subjects to be processed rather than treated as the proper subjects of the law. In any case, the further question is raised of why these general duties of solidarity must then be specified as duties of hospitality and in what relation these latter ones stand to the first-order, former ones.

Be that as it may, there are also some substantive issues with grounding the treatment of non-citizens in hospitality. The first problem is that hospitality still entails the asymmetrical relationship that I referred to in passing earlier in relation to charity. The host still remains an outsider and this already conditions the terms of the relationship. Hospitality might be denied; not everyone is always welcome in one's home. It follows that administrative expulsion on grounds of security and order is perfectly justified. Secondly, there are some obvious limits to the duties that can be imposed on guests. One would be unreasonable to blame a guest for minor infractions of the host's internal rules when it would not be unreasonable to have such expectations of those in the host country. Suppose that there is sufficient justification for this and that it is only a seeming departure from the Rule of Law. On a first reading, this beneficial differentiation in favour of guests might work in favour of non-citizens, as they would evade criminal responsibility for minor offences. On a closer look, however, we will see that it harbours the risk of actually obstructing the inclusion of non-citizens in the political community by severing the web of legal rules, subjection to which, as I argued earlier, provides the entry point into that political community. Therefore, whereas the aim of invoking hospitality as the ground of treating non-citizens as bearers of duties and rights was to include them in the political community, it might end up having exactly the opposite effect.

As I have already said, I consider a much more stable ground for premising the inclusion of third country nationals in the political community of a host country through their subjection to the criminal law and the legal system at large, duties which the political community, as represented by the state, might owe to its members. Let me then attempt, however briefly and tentatively, to ground how duties owed to citizens might ground a duty to include non-citizens in the criminal law as its proper subjects.

Suppose again that a third country national is radically excluded from the legal system at all, that one has no legal subjectivity in the host country. Suppose also that this third country national goes on to perform an act, which would have constituted the actus reus of a criminal offence had the third country national being granted the normative capacity to commit criminal offences. On the one hand, the act would not be a criminal offence because of the lack of normative capacity. It would be considered an accident and the victim might have some claim either against the state or private agents for compensation. But, at the same time, the act will have altered the normative position of the victim in relation to others, who are not liable to compensate her or otherwise redress this change in normative position. Property offences might provide the best possible example again here. Deprivation of the victim of her property rights will have an adverse impact on 
her normative relations with a much wider network of agents within the political community. If, however, the 'criminal' act is treated as an accident this impact will not be registered by the legal system whereas it would be, had the victim been recognised as the victim of crime.

The same is true, only from its reverse perspective, in the case of third country nationals who become victims of crime. To not recognise third country nationals as victims of crime amounts to not recognising the change in normative position of the perpetrator that the act brings about in relation to other, full subjects of the legal system, in the political community.

There is a further, auxiliary argument, which I will outline without discussing it in much detail. This is an argument from potentiality. Suppose again that a third country national is not afforded a right to participation in the political community at all and all her actions are acts of nature and therefore those actions of hers, which would otherwise form the actus reus of a criminal offence, can only be seen as accidents. This is quite obviously a distortion of the truth. Even if third country nationals are not given the status of legal subject, they have the basic capacity to be such subjects. Therefore, actual interactions by citizens with non-citizens always have the potential of being interactions between subjects of the law. To strip non-citizens of all legal subjectivity also amounts to deprive citizens of the ability to form new normative relations within the political community while the possibility of forging social relations remains intact. Recall Articles 29 and 30 of the Greek ISIC, which make third country nationals' status part of the actus reus of offences committed by citizens, as well as the fact that being in the country is a normative impossibility rendering all normative interactions between citizens and third country nationals impossible too thus distorting the social relations that in fact develop between the two parties. This amounts to depriving full members of the political community of the freedom to develop full-blown relations with others who have the potential of entering such relations. And from this, I would argue, stems a duty of the political community as represented by the state to realise this normative potential of third country nationals by granting them at least some access to the community's legal structure.

\section{CONCLUSION}

This article attempted two things. The first was to add some information to the study of criminalisation at the border in Europe by outlining some ways in which Greek law, much of which is in implementation of EU law, organises the normative exclusion of one class of immigrants therefore facilitating and legitimising their actual exclusion. Secondly, it tackled the theoretical question of whether such practices are justifiable. The crux of the argument is that no sooner is a non-citizen involved in the criminal law that a web of duties and rights is 
activated marking the gradual inclusion of the non-citizen in the political community as its proper subject. It follows that the differential treatment of noncitizens is ungrounded on the very terms of the legal system of the host country. It was also argued that it is both permissible and necessary for a state to treat noncitizens as the proper subject of the criminal law. The former, because of the implicit consent provided by non-citizens who engage in relations manifesting their intention to become a normative member of the political community; the latter out of respect for its own citizens, whose normative position is impacted on by their criminal law related interactions with non-citizens. 